\title{
Geographical Indications in Horticulture: North East India Perspective
}

\author{
Himadri Shekhar Datta ${ }^{*}$, Gargi Sharma², Sarat Sekhar Bora ${ }^{3}$ \\ ${ }^{1}$ College of Horticulture, ${ }^{2}$ Department of Plant Breeding \& Genetics, ${ }^{3}$ Agrometeorology, \\ KVK, Udalguri, Assam Agricultural University, Jorhat-785013, Assam, India
}

*Corresponding author

\begin{tabular}{|l|}
\hline K e y w o r d s \\
Geographical, \\
Product, Crop, Tag \\
\hline Article Info \\
\hline $\begin{array}{l}\text { Accepted: } \\
\text { 15 December } 2019 \\
\text { Available Online: } \\
\text { 20 January 2020 }\end{array}$ \\
\hline
\end{tabular}

\section{A B S T R A C T}

A geographical indication (GI) is a sign used on products that have a specific geographical origin and possess qualities or a reputation that are due to that origin (WIPO).Geographical Indication, an exclusive community rights, recognizes the importance of location, climate and human know how in making the products distinguished on the basis of their unique intrinsic attributes. It acts as an effective tool in protecting and rewarding the market potential of elite items and also the traditional knowledge associated with them (Kishore,2018). Since the enactment of the Geographical Indications of Goods(Registration and Protection) Act, 108 agricultural items have been accorded with GI tags till date and among them the horticultural items has its share of more than 75 percent. Among horticultural crops, maximum GIs have been accorded to fruit crops (38nos) followed by Plantation crops(14nos).Vegetable crops and spices share 12 and 13 GI tags whereas flower crops and aromatic plants conferred with 5 and 3 GI tags, respectively. North East India comprising of eight states is rich in diversity of many fruits, vegetables, flowers particularly orchids, spices and medicinal plants (Deka et al., 2012).It is evident from the list of registered GIs, how other states have quickly grabbed the opportunity and secured GI tagging of their goods and produce peculiar to their region. However, Northeast India, inspite of its rich horticultural diversity have not been able to take advantage of GI tagging. The horticultural produce of Northeast India got leg up with as many as 12 products accorded GI tags. GI tags will pave the way for better branding and marketing of these horticultural products both in domestic and international Market, besides protecting local crops and facilitating better return to legitimate rural producers. Thus, it is pertinent that a streamlined strategy should be adopted for tapping the untapped potential of the registered GI products, because unless that is done, the previous, ongoing as well as future registrations will have no sustainability (Sharma and Rajan, 2018). 


\section{Introduction}

North East India is sitting on hotspot of biodiversity of horticultural crops. Geographical Indications of the horticultural products with specific geographical origin to North East India is very much relevant in the present scenario as it protects the attributes and reputation of a product through market differentiation.A geographical indication (GI) is a sign used on products that have a specific geographical origin and possess qualities or a reputation that are due to that origin (WIPO). In order to be a GI, a sign must identify a product to be originating in a given place. Apart from that, the qualities, characteristics or reputation of the product should be essentially due to the place of origin. As the qualities depend on the geographical place of production, there is a clear link between the product and its original place of production. A geographical indication right enables those who have the right to use the indication to prevent its use by a third party whose product does not conform to the applicable standards(Chaudhary et al., 2017). Darjeeling Tea, Kangra Tea, Tezpur Litchi etc. are some of the GIs in the horticulture sector.

\section{Benefits of GI}

Higher market price: The profitability is primarily influenced by repute and quality of product,market size and degree of competition,consumer perception and demand elasticity.Geographical indications provide an effective platform for obtaining premium market price. Studies indicate that consumers are willing to pay higher price for origin guaranteed products.

Remunerative price for producers: Geographical indication would realise higher returns in global markets and establishing effective agricultural brands can help farmers gain a competitive advantage in 'buyer- driven' global markets.

Consumers: GI helps consumers get quality products of desired traits, protect consumers from deception. The qualities and uniqueness of the product create an image in the eye of consumers. So product becomes a brand for consumer.

Market penetration: A well-recognized brand with a strong reputation can help marketers penetrate new markets more easily. Favourable comments and advocacy by loyal customers also helps in facilitating access to new customers.

Traditional knowledge: The Traditional knowledge can be defined as the knowledge, innovations and practices of indigenous peoples and local communities. GI protects from loss of traditional lifestyles, misappropriation of Traditional Knowledge and its usage without any benefit-sharing.

Rural development: Protection of GI has significant implication on rural development by giving due recognition to our unique biodiversity and traditional knowledge. GI creates local jobs, prevent rural exodus and promotes rural tourism.

Legal Protection: It boosted exports of Indian geographical indications by providing legal protection and enables seeking legal protection in other WTO member countries.

\section{Types of GI}

\section{Geographical names}

Darjeeling, Kancheepuram

Non - Geographical names: Feni, Alphonso

Some examples of goods

Agricultural goods: Darjeeling Tea, Alphonso Mango

Natural goods: Makrana Marble

Manufactured goods:

Kolhapuri Chappal, Muga silk of Assam 
UNIQUENESS- Natural \& Human Factors

\section{Natural Factors}

Geographic factor (topography, soil, \& climate)

Colour\& Size

Chemical Constituents and

Oil Content

Use

\section{Human Element}

Human skill

Human labour

\section{Protection of GI}

Sui generis system

Collective or certification marks

Business practices, including administrative product approval schemes

\section{Historical development of GI}

At global level, prior to TRIPS, no Agreement dealing with the protection of GI as such.TRIPS Agreement (1994) is the First International legal instrument in which the term GI appears(Shukla,2016).The Agreement on Trade-Related Aspects of Intellectual Property Rights of 1994 ("TRIPS Agreement") provides the following definition:

"Geographical indications are, for the purposes of this Agreement, indications which identify a good as originating in the territory of a Member [of the World Trade Organization], or a region or locality in that territory, where a given quality, reputation or other characteristic of the good is essentially attributable to its geographical origin."

WTO members are free to implement in their law more extensive protection than is required by TRIPS; such protection must not contravene the provisions of the Agreement.

The Indian Parliament enacted in 1999, The Geographical Indications (GI) of Goods (Regulation and Protection) Act for registration and better protection in relation to goods. This Act came into effect on 15th September 2003. Under Section 1(e) it is defined that "Geographical Indication" in relation to goods, means an indication which identifies such goods as agricultural goods, natural goods or manufactured goods as originating or manufactured in the territory of a country or a region or locality in that territory, where a given quality reputation or other characteristic of such good is essentially attributed to its geographical origin and in case where such goods are manufactured goods, one of the activities of either the production or of processing or preparation of the goods concerned takes place in such territory, region on locality as the case may be. The focus of the Act is on quality reputation or other characteristic of such goods, which is essentially attributed to its geographical origin (Chaudhary et al., 2017).

The remedies available for GI protection

(i) Civil remedies

(ii) Criminal remedies

The Fourth Schedule of the Act classifies the goods into 34 classes with Coffee, Tea,and Spices under Class 30 and Agricultural and Horticultural products under Class 31 .

\section{Who can apply for GI?}

Any association of persons, producers, organization or authority established by under the law can apply.

The applicant must represent the interest of the producers 


\section{What does not qualify for GI?}

Things which are determined to be generic names or indications of goods not or ceased to be protected or which have fallen into disuse in that country

Things which contain any matter likely to hurt the religious susceptibilities of any class or section of the citizens of India

Things which would otherwise be disentitled to protection in a court

The use of which would be likely to deceive or cause confusion

The use of which would be contrary to any law in force

Things which comprise or contain scandalous or obscene matter

Things which although literally true as to the territory or region in which the goods originate, but falsely represent to the persons that the goods originate in another territory or region.

\section{Geographical Indication (GI) Logo \& Tagline}

Ownership rights of the Logo and Tagline vests in the Department forPromotion of Industry and Internal Trade(DPIIT,2019)

\section{What can be Geographical Indications?}

GI may be Agricultural product (Darjeeling Tea), Manufactured product (Kolhapuri Chappal), Food stuff (Bikaneri Bhujia), Naturalproduct (Makrana Marble)Wine \& Spirit Drink (Feni) and Handicraft (Muga Silk of Assam)

\section{Status of GI in Horticultural products in India}

Around 359 items accorded GI tags

Maximum GI granted to Handicraft (209)

Followed by Agricultural items (108)

Horticultural items covering more than $75 \%$ of items (85) (Kishore, 2018)

\section{Status of GI in Horticulture sector of Northeast India}

North East India comprising of eight states is rich in diversity of many fruits, vegetables, flowers particularly orchids, spices and medicinal plants. It is one of the hot spot in India, known for its diverse nature of soil, climate, and topography. Among the commercial fruits of the country, maximum diversity in citrus, banana and jack fruit are found in Northeast India. North East India has a very large number of diversity in other tropical and subtropical fruits belonging to the genera Garcinia, Annona, Averrhoa, Persia, Aegle, Passiflora and Tamarindusetc. The region is also rich in different genotypes of cucurbits, solanaceous vegetables, ginger, turmeric, bamboo, leafy vegetables etc. Among the different ornamental horticultural crops, the region displayed the maximum diversity in orchids, fern and other flowering shrubs. Indigenous and minor horticultural crops available in the region are however not being exploited properly (Deka et al., 2012).

It is evident from the list of registered GIs, other states have quickly availed the opportunity and obtained GI tagging of their goods and produce unique to their region. However, Northeast India, in spite of its rich horticultural diversity have not been able to take advantage of GI tagging.

The horticultural produce of Northeast India got leg up with as many as 12 products accorded GI tags.

\section{Naga Mircha}

Capsicum chinense: Plant height of 3 year old is $12-13$ feet

Recently been described as a distinct species Capsicum assamicumbased on morphological properties and proteomic 
analysis

Fruit colour Red, brown, white red with conical to semi conical shape and rough wrinkle surface

Recorded to be the hottest chilli in the world in 2006 with a Scoville heat unit (SHU) rating of $1,001,304$

Pungency reduced if grown in bright places Very high capsaicinoid content $2.45 \%$ to $5.36 \%$.As other varieties have capsaicinoid less than $1 \%$,so ideal for capsaicin extraction since $1 \%$ capsaicin is standard for commercial extraction

Fruity aroma, distinctive pungency and exquisite unique taste are the special characteristics(Gogoiet al., 2018; Meeteiet al., 2016)

\section{Naga Tree Tomato}

Solanumbetaceum: Perennial shrub, grown as a backyard venture crop

Small, tender 10-18 feet tall tree, which bears fruits which are oval and egg shaped and grows in clusters

Varied from red to orange with inside pulp of the fruit is light orange and the seeds are black

The fruit weight usually 100 to $150 \mathrm{~g}$ and has sweet taste and resinous aroma

It has relatively thicker outer skin, less moisture content and long shelf life

Helps to controlling in High Blood Pressure and brings down cholesterol levels

Special organoleptic quality, sweetness with more carbohydrates and protein

(Rai et al., 2005; NERAMAC, 2014)

\section{Arunachal Orange}

Oranges cultivated in the climatic conditions of Arunachal Pradesh

Citrus reticulata: Trees grow between 3 - $6 \mathrm{~m}$ high

Fruit round with medium thick peel \& weights $100-150 \mathrm{~g}$
Distinguished by loose skin of fruit, the relative ease with which the segments can be separated

High TSS \& medium acidity provides unique sweet sour taste

Orange colour at fruit ripening with high Vitamin $\mathrm{C}$ and high juice content

(NERAMAC, 2014)

\section{Sikkim Large Cardamom}

Important cash crop of Sikkim and Darjeeling Amomumsubulatum: Perennial herb with aerial leafy shoots of height of 1.7 to $2.6 \mathrm{~m}$ and possess 9 to 13 leaves in each tiller

Inflorescence is a condensed spike with yellowish perianth of 10-15 fruits

Fruit round or oval shape, capsule with reddish brown colour

Shade loving tree, supports conservation of tree biodiversity

Superior quality because of native environment \& traditional system of curing

Quality different from small cardamom with lower volatile oil content \& more fibrous

Traditional knowledge of curing with controlled heat to ensure proper and uniform drying(NERAMAC, 2014)

\section{Mizo Chilli}

Capsicum frutescens:Characterized by a bushy type of plant growing up to 120 $\mathrm{cm}$. The leaves are smooth oval shaped

Fruit small sized pod, highly pungent,mature fruit is dark red

Stands apart because of its smaller size with $37,153 \mathrm{SHU}$

High $\mathrm{K}$ in the jhum lands responsible for distinctive red color

Burning of field helps in reducing the weed growth,soft rot disease and increase the availability of certain plant nutrients 
particularly potash which helps the crop grow well and provides good colour to the final fruit

Free from pesticide residue

Capsaicin content of $0.59 \%$ (NERAMAC, 2014)

\section{KarbiAnglong Ginger}

Zingiber officinale: It is an herbaceous perennial, unbranched, pseudo-stems or aerial shoots reach a height of $30-90 \mathrm{~cm}$

Mostly two varieties of ginger viz., Nadia \&Aizol cultivated. Bhola is also

cultivated in the district

Nadia variety is medium to bold, light brown incolour, moderately pungent and have mild flavor with Oleoresin content $3.40 \%$

Aizol variety is large rhizome with less fibre content (NERAMAC,2014)

\section{Tripura Queen Pineapple}

Ananascomosus: medium tall (1.0-1.5 m) herbaceous perennial plant with

30 or more trough-shaped and pointed leaves $30-100 \mathrm{~cm}$ long

Fruits are spiny $\&$ orange yellow in color

Sweetness and unique aroma

Fruits oval in shape with golden yellow pulp

Smaller fruits with lesser fibre content

Not suitable for slices due to of its smaller size \& deep eyes

Juice content $23.68 \%$,sugar content more but less acidity

(NERAMAC, 2014)

\section{Tezpur Litchi}

Tezpur Litchi is a special type of Litchi grown in LitchuPukhuri and Porowa village of Sonitpur district of Assam

Pleasant flavour, juicy pulp (aril) with attractive colour\& small seed with tight pulp Size weighs around 70-80 $\mathrm{g}$ and high Total sugar content $15.59-16.28 \mathrm{~g} / 100 \mathrm{~g}$ are the special characters

\section{Khasi Mandarin}

Citrus reticulata: small size \& evergreen trees with pronounced upright growth habit

Fruitglobose to oblate and distinguished by tight and smooth skin

Not easy to peel, but has more flesh and juice

Rind medium-thick, fairly loosely adherent with prominent, sunken oil glands

Flesh color orange; fruits loses quality and rind puffs if not picked when ripe.

Rich source of Vitamin Cwith TSS ( ${ }^{\circ}$ Brix) 11.56 and Acidity $0.64 \%$

(GI Registry Journal,2014)

\section{Kachai Lemon}

Citrus jambhiri: High yielding land race of lemon in Ukhrul district of Manipur

Fruits are spheroid in shape and the individual fruit weight ranges from 70 to $100 \mathrm{~g}$. and are yellow in colour

Uniqueness of the fruit lies in its bearing habit. Even if it gets ripened it doesn't fall from the tree

Unplucked fruits remain on the tree and the fruits change its colour in next fruiting season (green to yellow)

The rind colour is white and the pulp colour is yellow

Fruit is a rich source of Ascorbic Acid, containing $46-51 \mathrm{mg} / 100 \mathrm{ml}$ juice.

TSS is $6.8-10.5 \circ$ Brix and Acidity 4.1-6.1\%

(MOMA, Govt of Manipur;GI Registry, 2014). 
Table.1 List of GI registered Horticultural products of India

\begin{tabular}{|c|c|c|}
\hline Crop & Name & Geographical area \\
\hline \multicolumn{3}{|c|}{ Fruit Crop (38nos.) } \\
\hline \multirow[t]{9}{*}{ Mango } & MaldalaxmanBhog Mango & West Bengal \\
\hline & Maldakhirsapati (Himsagar) Mango & West Bengal \\
\hline & Maldafazil Mango & West Bengal \\
\hline & Mango malihabadiDusseheri & Uttar Pradesh \\
\hline & Appemidi & Karnataka \\
\hline & Marathwadakesar & Maharashtra \\
\hline & Banaganpalle mangoes & Telangana\& Andhra Pradesh \\
\hline & Alphonso & Maharashtra \\
\hline & Bhagalpurizardalu & Bihar \\
\hline \multirow[t]{7}{*}{ Citrus } & Coorg orange & Karnataka \\
\hline & Nagpur orange & Maharashtra \& MP \\
\hline & Arunachal orange & Arunachal Pradesh \\
\hline & Khasi mandarin & Meghalaya \\
\hline & Kachai lemon & Manipur \\
\hline & Memongnarrang & Meghalaya \\
\hline & Jalna Sweet orange & Maharashtra \\
\hline \multirow[t]{6}{*}{ Banana } & Nanjanagud banana & Karnataka \\
\hline & Chengalikodannendran Banana & Kerala \\
\hline & Virupakshi hill Banana & Tamil Nadu \\
\hline & Sirumalai hill Banana & Tamil Nadu \\
\hline & Kamalapur red Banana & Karnataka \\
\hline & Jalgaon banana & Maharashtra \\
\hline \multirow[t]{3}{*}{ Grapes } & Nashik grapes & Maharashtra \\
\hline & Bangalore blue Grapes & Karnataka \\
\hline & Sangli raisins & Maharashtra \\
\hline Pomegranate & Solapur pomegranate & Maharashtra \\
\hline Strawberry & Mahabaleshwar strawberry & Maharashtra \\
\hline \multirow[t]{3}{*}{ Pineapple } & Vazhakulam & Kerala \\
\hline & Tripura Queen & Tripura \\
\hline & Vazhakulam & Kerala \\
\hline Guava & Allahabad surkha & Uttar Pradesh \\
\hline Kokum & Sindhudurg\&Ratbagiri kokum & Maharashtra \\
\hline \multirow[t]{2}{*}{ Litchi } & Tezpur litchi & Assam \\
\hline & Shahi litchi of Bihar & Bihar \\
\hline Pomello & Devanahallipomello & Karnataka \\
\hline $\begin{array}{l}\text { Custard } \\
\text { Apple }\end{array}$ & Beed Custard apple & Maharashtra \\
\hline
\end{tabular}




\begin{tabular}{|c|c|c|}
\hline Fig & Purandar fig & Maharashtra \\
\hline Chikoo & DahanuGholvadchikoo & Maharashtra \\
\hline \multicolumn{3}{|c|}{ Vegetable crop (12nos.) } \\
\hline \multirow[t]{7}{*}{ Chilli } & Naga Mircha & Nagaland \\
\hline & Guntur sannam chilli & Andhra Pradesh \\
\hline & Bydagi chilli & Karnataka \\
\hline & Bydagi chilli & Karnataka \\
\hline & Mizo chilli & Mizoram \\
\hline & Bhiwapur chilli & Maharashtra \\
\hline & Khola chilli & Goa \\
\hline \multirow[t]{2}{*}{ Brinjal } & UdupiMattuGullabrinjal & Karnataka \\
\hline & JalgaonBharatibrinjal & Maharashtra \\
\hline Bean & Waghyaghevada & Maharashtra \\
\hline \multirow[t]{2}{*}{ Onion } & Banglore rose onion & Karnataka \\
\hline & Lasalgaon onion & Maharashtra \\
\hline Tree Tomato & Naga tree tomato & Nagaland \\
\hline \multicolumn{3}{|c|}{ Plantation crops (14nos.) } \\
\hline \multirow[t]{4}{*}{ Tea } & Darjeeling tea & West Bengal \\
\hline & Kangra tea & Himachal Pradesh \\
\hline & Nilgiriorthodoxt & Tamil Nadu \\
\hline & Assam orthodox & Assam \\
\hline \multirow[t]{7}{*}{ Coffee } & Monsooned Malabar arabica coffee & Kerala \\
\hline & Monsooned Malabar robusta coffee & Karnataka \\
\hline & CoorgArbica coffee & Karnataka \\
\hline & Wayanaadrobusta coffee & Kerala \\
\hline & Chikmagalur Arabica coffee & Karnataka \\
\hline & Arku valley arabica coffee & Andhra Pradesh \& Orissa \\
\hline & Bababudangirisarabica coffee & Karnataka \\
\hline Coconut & Eathomozhy tall coconut & Tamil Nadu \\
\hline Cashew & Vengurla Cashew & Maharashtra \\
\hline Areca nut & SirsiSupari & Karnataka \\
\hline \multicolumn{3}{|c|}{ Spices (13nos.) } \\
\hline \multirow[t]{3}{*}{ Cardamom } & Sikkim Large cardamom & Sikkim \\
\hline & Alleppey Green cardamom & Kerala \\
\hline & Coorg Green cardamom & Karnataka \\
\hline Ginger & Assam KarbiAnglong Ginger & Assam \\
\hline \multirow[t]{2}{*}{ Pepper } & Malabar Pepper & Kerala \\
\hline & Tellicherry Pepper & Kerala \\
\hline \multirow[t]{2}{*}{ Turmeric } & Waligoan Turmeric & Maharashtra \\
\hline & Sangli Turmeric & Maharashtra \\
\hline
\end{tabular}




\begin{tabular}{|c|c|c|}
\hline & Erode Turmeric & Tamil Nadu \\
\hline & KandhamalHaladi & Orissa \\
\hline Bay leaf & UttarkhandTejpat & Uttarkhand \\
\hline KalZeera & Himachali Kala Zeera & Himachal Pradesh \\
\hline Garlic & Kodaikanalmalaipoondu & Tamil Nadu \\
\hline \multicolumn{3}{|c|}{ Flower (5nos.) } \\
\hline \multirow[t]{4}{*}{ Jasmine } & Mysore Malligae & Karnataka \\
\hline & HadagaliMalligae & Karnataka \\
\hline & UdupiMalligae & Karnataka \\
\hline & Madurai Malli & Tamil Nadu \\
\hline Kewda & GanjamKewda flower & Odisha \\
\hline \multicolumn{3}{|c|}{ Aromatic plants (3nos.) } \\
\hline \multirow[t]{3}{*}{ Betel Leaf } & Mysore betel leaf & Karnataka \\
\hline & Magahi Paan & Bihar \\
\hline & Tirur betel leaf & Kerela \\
\hline
\end{tabular}

Table.2 The Horticultural Products of North East India with GI tag

\begin{tabular}{|c|c|}
\hline Horticultural Item & State \\
\hline Assam Orthodox Tea & Assam \\
\hline Naga Mircha & Nagaland \\
\hline Naga Tree Tomato & Nagaland \\
\hline Arunachal Orange & Arunachal Pradesh \\
\hline Large Cardamom & Sikkim \\
\hline Mizo Chilli & Mizoram \\
\hline Assam KarbiAnglong Ginger & Assam \\
\hline Tripura Queen Pineapple & Tripura \\
\hline Tezpur Litchi & Assam \\
\hline Khasi Mandarin & Meghalaya \\
\hline Kachai Lemon & Manipur \\
\hline MemongNarang & Meghalaya \\
\hline
\end{tabular}


Table.3 Varieties of Tezpur Litchi

\begin{tabular}{|l|l|l|l|l|l|}
\hline Variety & Fruit size/shape & Colour & Flesh & Sweetness & $\begin{array}{l}\text { Fruiting } \\
\text { habit }\end{array}$ \\
\hline Ilachi & $\begin{array}{l}\text { Round \&small. Seed } \\
\text { small. Grape like shape }\end{array}$ & Shendury & Compact & $\begin{array}{l}\text { Sugar sweet \& } \\
\text { scented }\end{array}$ & Medium \\
\hline Bilaiti & $\begin{array}{l}\text { Round \& very large. } \\
\text { Apple shaped, small } \\
\text { seed }\end{array}$ & Brick red & $\begin{array}{l}\text { Compact \& } \\
\text { scented }\end{array}$ & Sugar sweet & Profuse \\
\hline Bombay & $\begin{array}{l}\text { Round \& very large. } \\
\text { Small seed. shape like } \\
\text { strawberry }\end{array}$ & Brick red & $\begin{array}{l}\text { Compact \& } \\
\text { scented }\end{array}$ & $\begin{array}{l}\text { Sweet but } \\
\text { slightly sour }\end{array}$ & Profuse \\
\hline Piyaji & $\begin{array}{l}\text { Elongate \& medium } \\
\text { large }\end{array}$ & Brick red & $\begin{array}{l}\text { Loose pulp } \\
\text { scented } \\
\text { like onion }\end{array}$ & Sweet sugar & Alternate \\
\hline Haldia & Elongated large seed & $\begin{array}{l}\text { Yellowish } \\
\text { red }\end{array}$ & Compact & Sweet & Medium \\
\hline
\end{tabular}

(Source: NERAMAC, 2014)

Table.4 Some Horticultural GIs under Examination from North East India

\begin{tabular}{|c|c|c|c|}
\hline Name of the product & Location & Special character & Reference \\
\hline Mizobanana & Mizoram & attractive size, shape and taste & GI Registry,2019 \\
\hline Assam lemon & Assam & Cluster bearing habit, seedless fruits & GI Registry,2019 \\
\hline Naga cucumber & Nagaland & $\begin{array}{l}\text { Low in calories, high in potassium and } \\
\text { contain high level of water. }\end{array}$ & GI Registry,2019 \\
\hline $\begin{array}{l}\text { ManipurBlack } \\
\text { Cherry }\end{array}$ & Manipur & $\begin{array}{l}\text { Natural edible colour } \\
\text { high moisture content }\end{array}$ & NERAMAC,2017 \\
\hline Assam elephant apple & Assam & $\begin{array}{l}\text { Used curries, } \\
\text { traditional medicine }\end{array}$ & NERAMAC,2017 \\
\hline Leteku & Assam & $\begin{array}{l}\text { High potassium content } \\
\text { Rich source of pectin }\end{array}$ & NERAMAC,2017 \\
\hline DalleKhorsani & Sikkim & Unique flavour and high pungency & GI Registry,2018 \\
\hline MizoChow chow & Mizoram & $\begin{array}{l}\text { Low caloric value } \\
\text { Wide adaptability }\end{array}$ & GI Registry,2018 \\
\hline SiroiLily & Manipur & bell shaped petals & GI Registry,2017 \\
\hline Passion fruit & Mizoram & $\begin{array}{l}\text { small in size, its flavour is excellent } \\
\text { and less acidic }\end{array}$ & GI Registry,2018 \\
\hline Rahre & $\begin{array}{l}\text { Arunachal } \\
\text { Pradesh }\end{array}$ & $\begin{array}{l}\text { rich source of essential oil } \\
\text { adapted to biotic \&abiotic stress }\end{array}$ & GI Registry,2017 \\
\hline Tamenglong Orange & Manipur & sweet- sour taste and high juice content & GI Registry, 2017 \\
\hline
\end{tabular}


Table.5 Some horticulturalproducts of North East India with potential for GI

\begin{tabular}{|c|c|c|}
\hline $\begin{array}{l}\text { Name of the } \\
\text { product }\end{array}$ & Location & Special character \\
\hline Longaibrinjal & $\begin{array}{l}\text { Karimganj, } \\
\text { Assam }\end{array}$ & $\begin{array}{l}\text { Soft, very less seed, more flesh with unique } \\
\text { aroma(Datta,2016) }\end{array}$ \\
\hline Maroinapakpi & Manipur & $\begin{array}{l}\text { Associated with traditional recipes and also with the } \\
\text { ethnotherapy of certain diseases (Ayam,2011) }\end{array}$ \\
\hline Tree bean & $\begin{array}{l}\text { Manipur/ } \\
\text { Mizoram }\end{array}$ & $\begin{array}{l}\text { Flowers, tender pods and seeds edible \&a good source of } \\
\text { proteins, fats, carbohydrates, vitamins and minerals(Roy } \\
\text { et al., 2016) }\end{array}$ \\
\hline Bhimkol & Assam & $\begin{array}{l}\text { Very good infant food, source of bio antacid. (Borborahet } \\
\text { al., 2016) }\end{array}$ \\
\hline Darjeeling banana & Manipur & $\begin{array}{l}\text { Pseudostems green, tinged with brownish colour,leaf } \\
\text { sheath bases not enclosing pseudostems, blotched with } \\
\text { black-brown spots, waxy when young, devoid of wax on } \\
\text { maturity (Singh et al., 2016) }\end{array}$ \\
\hline Moran Ada & Assam & $\begin{array}{l}\text { Moran Ada is very rich in oil\&has medicinal } \\
\text { properti(Hazarika and Kakoti,2013) }\end{array}$ \\
\hline $\begin{array}{l}\text { Senduriaam, } \\
\text { Matiaam } \\
\text { Tilikiaam }\end{array}$ & Assam & $\begin{array}{l}\text { Unique flavour and taste } \\
\text { (The Sentinel,June 27, 2019) }\end{array}$ \\
\hline $\begin{array}{l}\text { Rhynchostylisretusa } \\
\text { Vanda coerulea } \\
\text { Orchislatifolia } \\
\text { Dendrobiumhookeri } \\
\text { anum }\end{array}$ & $\begin{array}{l}\text { NorthEast } \\
\text { India }\end{array}$ & $\begin{array}{l}\text { Traditional medicine } \\
\text { Traditional food } \\
\text { Cattle feed(Medhi\& Chakrabarti,2009) }\end{array}$ \\
\hline $\begin{array}{l}\text { AssamiyaPaan } \\
\text { GaanPaan }\end{array}$ & Assam & $\begin{array}{l}\text { Have high leaf pungency } \\
\text { Profuse branching habit (Maiti\& Saikia,2002) }\end{array}$ \\
\hline
\end{tabular}

Table.6 SWOT Analysis of Horticultural GI in North East India

\begin{tabular}{|l|l|}
\hline Strength & Weakness \\
\hline Agro climatic diversity & Poor socio economic condition \\
\hline History of Organic farming & Lack of market access \\
\hline Proximity to export destinations & Slow pace in adoption of technology \\
\hline Adequate rainfall during monsoon & Subsistence farming \\
\hline Potential to commercialize & Lack of business acumen \\
\hline Opportunity & Threat \\
\hline $\begin{array}{l}\text { Organic farminng } \\
\text { Infrastructural facilities can be created } \\
\text { with private sector participation }\end{array}$ & Growing interest of rural youth towards off-farm job \\
\hline $\begin{array}{l}\text { Govt policies for NER specially 'Look } \\
\text { East Act East' }\end{array}$ & Uncertainty in external trade scenario \\
\hline Scope for value addition & Insurgency \\
\hline
\end{tabular}




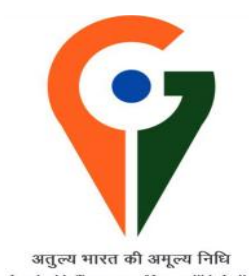

Fig.1 GI Registration Trend in Indian Sectors (Source: Kulkarni and Konde, 2011)

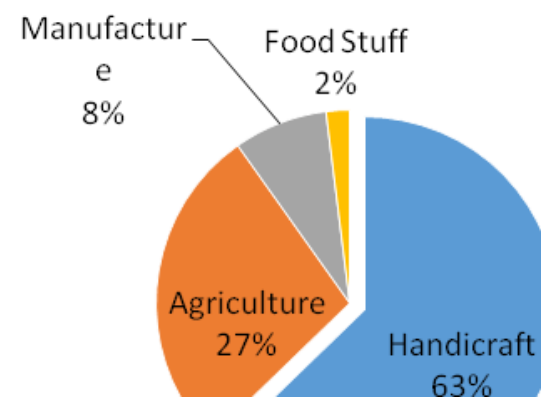

Fig.2 Geographical Indications in Horticultural crops (Kishore, 2018)

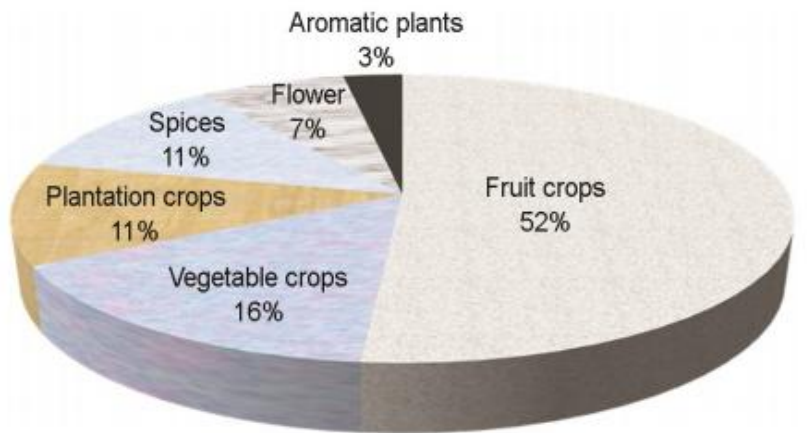

Fig.3 Statewise ownership of Geographical Indications in Horticultural crops (Kishore, 2018)

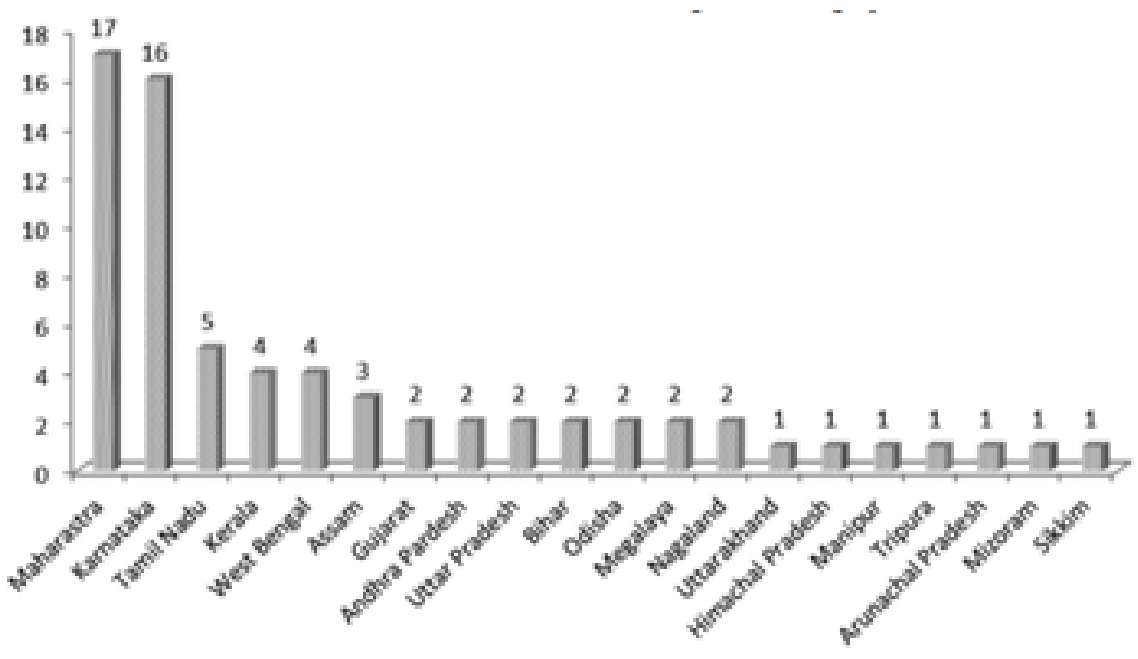


Fig.4 Trends in allotment of Geographical Indications in Horticultural crops (Kishore, 2018)

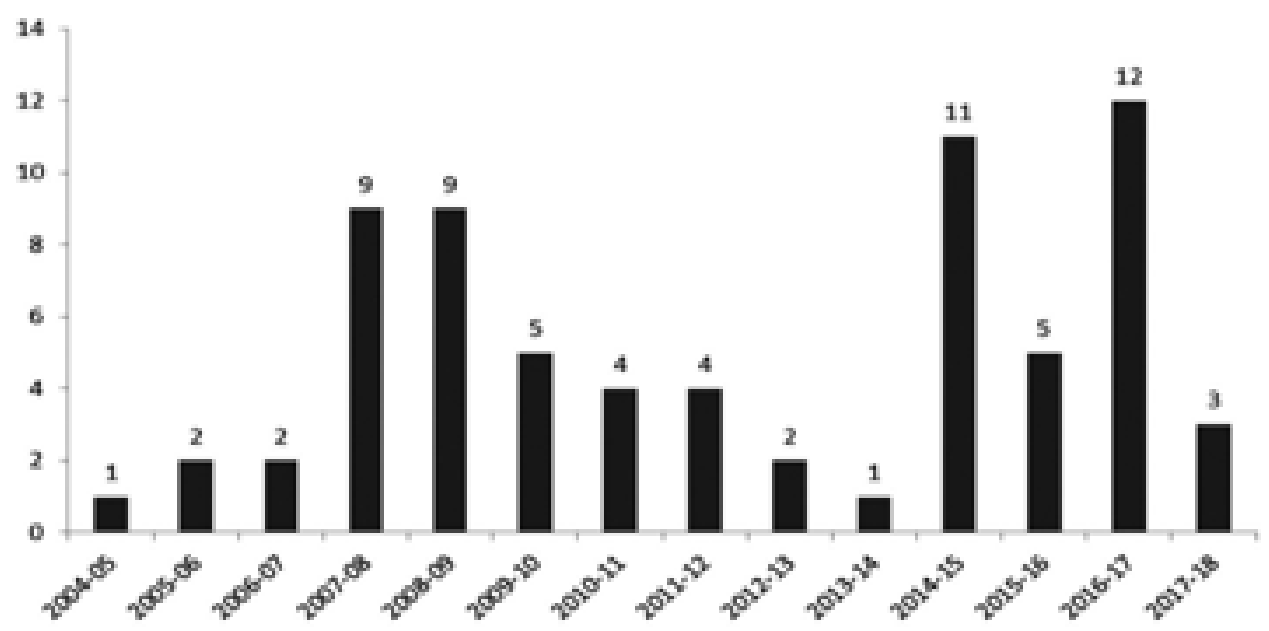

Fig.5 Status of GI in Horticulture sector of Northeast India (Source: Lyngdoh et al., 2016)

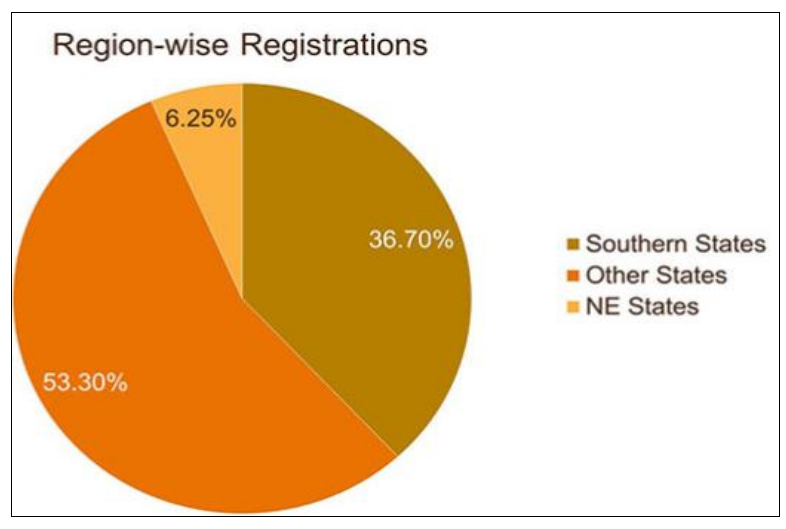

\section{Assam (Orthodox) Tea}

With its special aroma and bold \& malty flavor, Assam tea is the preferred beverage for many in the world.

Teas "that are grown and manufactured out of the basic Camelliasinensis var. assamica and other variants in the Brahmaputra or Assam Valley in north east India"

Assam Orthodox Teas are rolled with machinery in a manner that mimics hand-rolling. Most of the specialty tea are made with orthodox production methods

Two flush with $1^{\text {st }}$ flush: March and $2^{\text {nd }}$ flush:
May-June

Bright yellow colour with unique taste (GI Registry Journal,2007)

\section{MemangNarang}

Citrus indica: very small tree or shrub 3-6 feet tall.

Fruits are spherical to depressed globose, with smooth surface

Fruits are deep orange red to almost scarlet when full ripe

Can be used as a rootstock as virtually free from pest $\&$ diseases.

Fruits very small in size and flavor not agreeable, mostly used as medicine 
Nokrek Biosphere Reserve is the natural home of the Endangered species

Germplasm conserved at the National Citrus Gene Sanctuary in the Reserve

(GI Registry Journal, 2014)

\section{Geographical Indications protecting Traditional Knowledge}

Traditional knowledge (TK) can be defined as the knowledge, innovations and practices of indigenous peoples and local communities

GI gives protection against misappropriation of TK, and its usage without any benefitsharing

GI can create economic rewards for producers \&enhance commercial value

\section{Kolakhar: Traditional Knowledge of Assam}

Kolakhar is a traditional ingredient and a popular food additive in Assam

It is known to help normalizing digestive disorders of stomach

It is generally prepared from the ash of Musa balbisiana(Bhimkol)

Kolakhar have pH 13

Kolakhar,a traditionally known antacid is rich in Potassium Carbonate

(Deka and Talukdar,2007;Hemanta et al., 2014)

\section{Issues and concern}

GI status not exploited post registration

Lack of background work for filing and awareness

Limited Consumer Awareness of GI

Lack of initiatives in building brands and visibility

Lack of formal organization structures and/or control mechanisms

Requirement of support in terms of $R \& D$, marketing etc
Conclusion and future prospects are as follows:

Protect \& exploit market potential of origin linked reputed products

Defence against unfair competition

Effective inter institutional linkages and coordination

Need of the hour to spread GI literacy

Option for Doubling Farmers income

Developing, registering and enforcing a GI

can be time consuming and needs to be addressed

Strict implementation of rules and regulations

\section{References}

Annon. (2019). Guidelines for permitting the use of Geographical Indications (GI) Logo and Tagline-seeking stakeholders comment. Department for Promotion of Industry and Internal Trade, New Delhi.

Annon.(2019). Kachai Lemon.Manipur Organic Mission Agency.Retrieved on 06.9.2019 from https://momamanipur.com/kachailemon.

Annon. (2019). The Registration Process.Geographical Indications Registry.Retrieved 06.9.2019 from http://www.ipindia.nic.in/the-registrationprocess-gi.htm.

Ayam,V.S.(2011). Allium hookeri, Thw.Enum. A lesser known terrestrial perennial herb used as food and its ethnobotanical relevance in Manipur.Afr.J Food Agri.Nutr.Dev.11(6):5389-5412.

Borborah, K., Borthakur, S.K. and Tanti, B. (2016).Musa balbisianaCollaTaxonomy,Traditional Knowledge and Economic potentialities of the plant in Assam,India.Ind.J.Trad.Knowl.15(1):116120.

Chaudhary, R.C., Yadav, S.K. and Kumar, S. (2017). Geographical Indications in Indian Agriculture on the anvil.J.Bio.Innov.6(5): 790-816.

Datta,H.S.(2016).LongaiBrinjal,the indigenous variety of Karimganj district. In: Souv. 


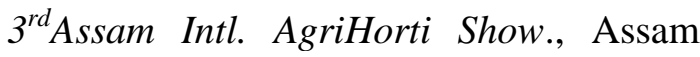
Hort. Society, pp.77-78

Deka, B. C., Thirugnanavel, A., Patel, R. K., Nath, A. and Deshmukh, N. (2012).Horticultural diversity in NorthEast India and its improvement for value addition.Indian J. Genet.72(2): 157-167.

Deka, D.C. and Talukdar, N.N. (2007).Chemical and Spectroscopic investigation of Kolakhar and its commercial importance.Ind.

Trad.Knowl.6(1):72-78

Gogoi, J., Barman, I. and Murrey, E. (2018).Journey of Capsicum from wild Chili to world hottest Chilli (Naga King Chili).Int. J. Pharm. Biol.Sci.8(3):835-840.

Hazarika, D.J.and Kakoti, M., (2013).Study on the Indigenous Varieties of Ginger of Golaghat District (Assam), and its Economic Viability as Aroma Ingredients.J. Nat. Prod. Plant Resour.3(1):24-29.

Hemanta, M.R., Mane, V.K. and Bhagwat, A. (2014).Analysis of Traditional Food Additive Kolakhar for its PhysicoChemical Parameters and Antimicrobial Activity.J Food Process Technol. 5:11.

Kishore, K. (2018). Geographical Indications in Horticulture: An Indian Perspective. J Int. Prop. Rights.23: 159-166.

Kulkarni,V. and Konde,V. (2011).Pre- and Post- Geographical Indications Registration Measures for Handicrafts in India.J Int. Prop. Rights.16: 463-469.

Lyngdoh, P. (2016).A Look at the Geographical Indication Status of Northeast.Retrieved 06.9.2019 from https://explorers.zizira.com/know-food- comes-look-geographical-indicationstatus-northeast.

Maiti,S. and Saikia,L.(2002).Genetic Resources of Betelvine in India. In: Tech.Bull.AICRP on Betelvine.Assam Agril. Univ., Assam. pp.1-31.

Medhi,R.P.

and

Chakrabarti,S.(2009).Traditional

Knowledge of NE people on conservation of wild orchids. Ind. J.Trad.Knowl. 8(1):11-16.

Meetei, N.T., Singh, A.K., Singh,B.K. and Mandal,N.(2016).Recent advances in Naga King Chilli (Capsicum chinense JACQ) research.Int. J. Agri. Env. Biotech.9(3): 421-428.

Rai,N. Asati,B.S., Patel,R.K.,Patel,K.K. and Yadav,D.S.(2005). Underutilized Horticultural Crops in North Eastern Region.ENVIS Bull.: Himal. Ecol.13(1): 21-26.

Roy, S.S. Kumar, S., Sharma, S.K.,Devi,A.R.,Singh,N.A.,Prakash, O. and Ngachan,S.V.(2016). Tree Bean (Parkiaroxburghii): A Potential Multipurpose Tree Legume of North East India. In:Natl. Symp.Veg.Legu.Soil Hum.Health. (February 12-14, 2016).pp: 201-208.

Sharma, M. and Rajan, S. (2018). Improvising GIs significance in fruit crops for doubling farmers income. J. Pharm. Phytochem.7(2): 1903-1905.

Singh,W.A., Handique,P.J. and Devi,H.S.(2016).Musa sikkimensisKurz (Musaceae): A note on the rediscovery from Manipur, India. Fol.malaysi.17(1): $47-53$.

\section{How to cite this article:}

Himadri Shekhar Datta, Gargi Sharma and Sarat Sekhar Bora. 2020. Geographical Indications in Horticulture: North East India Perspective. Int.J.Curr.Microbiol.App.Sci. 9(01): 1207-1221. doi: https://doi.org/10.20546/ijcmas.2020.901.134 